\title{
Electron microscopic observations on the virus particles in Herpes simplex encephalitis
}

\author{
S. ROY AND L. WOLMAN \\ From the Department of Neuropathology, Royal Infirmary, Sheffield
}

SYNOPSIS Cerebral cortex from eight fatal cases of Herpes simplex encephalitis has been studied by electron microscopy. The diagnosis had been based on clinical findings, necropsy evidence of bitemporal necrosis, and histological confirmation of intranuclear inclusions with a lymphocytic inflammatory response, even though virus cultures were unsuccessful. Virus particles were seen predominantly in nuclei in six of these cases, utilizing tissue which had been preserved in formalin for up to four years or had been embedded in paraffin. Although demonstration of these particles is only indicative of the herpes group and not specifically of Herpes simplex, electron microscopy of either biopsy or postmortem material may be a useful adjunct in making the diagnosis and can be accomplished before virological studies have been completed.

In Britain cases of epidemic and insect-transmitted encephalitis are rare. However, encephalitis caused by Herpes simplex virus occurs frequently in sporadic form (Grist, 1967). Similar experience has been reported from other countries (Rawls, Dyck, Klass, Greer, and Herrmann, 1966; May, Dahn, and Reuss, 1967). This disease has also been described as acute necrotizing encephalitis (Van Bogaert, Radermecker, and Devos, 1955). It is characterized by widespread inflammation of the meninges and brain associated with severe necrosis and usually presents clinically as an acute pyrexial illness of the central nervous system. In a typical case, one or both temporal lobes are most affected. If predominantly unilateral, the clinical picture may be confused with an expanding lesion of the temporal lobe, such as tumour or abscess, making it difficult to reach a clinical diagnosis.

The chance of any treatment to be beneficial will be increased by its early institution. It is, therefore, very important to diagnose the disease with certainty as quickly as possible. Several techniques may be employed for this purpose including temporal lobe biopsy, virus culture from brain, cerebrospinal fluid, pharyngeal washing and faeces, a gamma scan (Balfour, Loken, and Blaw, 1967) to demonstrate bitemporal lesions, sequential serological studies for antibodies, and the fluorescent antibody technique (Biegeleisen, Scott, and Lewis, 1959). The difficulties in finding and being certain of the Received for publication 13 June 1968. viral origin of inclusion bodies in biopsy and necropsy material and the time interval involved in culturing virus, frequently without success due to numerous factors (Wolman, 1967), led us to use the electron microscope to identify virus particles in infected material. This technique, we believe, may be of great help in reaching both an early diagnosis in life as well as in the recognition of the disease in postmortem material, especially in cases where the diagnosis remains indefinite on routine histological examination.

\section{MATERIAL AND METHODS}

Material from eight fatal cases of encephalitis was examined with the electron microscope. Of these four came from postmortem specimens of whole brains fixed in formalin for a period of one month to four years. Tissues for electron microscopy were collected from the superficial regions of the cerebral cortex, an area likely to be accessible by the biopsy needle. In one case a small amount of material was removed through burrholes from both temporal lobes after the death of the patient, permission to do a complete necropsy having been refused (case 7). In the other three cases, tissue previously embedded in paraffin blocks was used (cases 2, 3, and 6). Brief clinical and pathological details, with duration of illness and virus findings, are given in Table I. Small blocks (1 mm cube) of formalin-fixed or deparaffinized material were thoroughly washed in veronal acetate buffer before post fixation in buffered osmium tetroxide (Palade, 1952). Tissues in all cases included blocks from one or both 
TA B LE I

CLINICO-PATHOLOGICAL DATA

\begin{tabular}{lcccr} 
Case & Sex & Age & $\begin{array}{c}\text { Duration of } \\
\text { IIness (Days) }\end{array}$ & $\begin{array}{r}\text { Duration } \\
\text { Neurolo } \\
\text { Sympto }\end{array}$ \\
\hline 1 & F & 2 & 5 & 4 \\
2 & M & 2 & 5 & 5 \\
3 & M & 43 & 11 & 11 \\
4 & F & 43 & 12 & 9 \\
5 & M & 41 & 13 & 10 \\
6 & F & $2 \frac{1}{2}$ & 15 & 13 \\
7 & F & 10 & 17 & 14 \\
8 & F & $1 \frac{1}{2}$ & 30 & 26
\end{tabular}

temporal lobes and at least one frontal lobe and in two also from one occipital lobe. In three cases blocks from the pons and/or midbrain were also examined. Blocks from the temporal lobes of four brains of patients who died of causes other than encephalitis were also examined. This latter group was designed to serve as a control.

After osmium fixation all the tissues were dehydrated in graded alcohol and were further processed and embedded in araldite (Glauert, 1961). Sometimes the processing time was reduced by using the method of Lynn, Martin, and Race (1966). Thin sections were cut in a Porter-Blum microtome, mounted on uncoated copper grids, stained with lead citrate (Reynolds, 1963), and examined under the AEI EM6 electron microscope using an accelerating voltage of 50 or $75 \mathrm{kv}$.

In all cases at least three blocks from each of the temporal lobes were examined and up to six blocks from other areas. No tissue from any other organ was available for examination.

\section{RESULTS}

In all these cases there was evidence of necrosis of both temporal lobes on gross and microscopic examination (Fig. 1) associated with perivascular

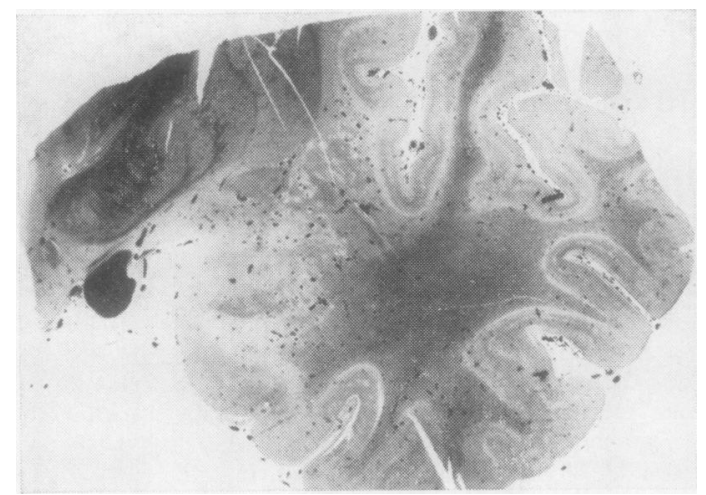

FIG. 1. Coronal section of temporal lobe of case 2 showing necrosis with pallor of staining of cortex and superficial white matter on medial and inferior aspects. There is marked congestion of blood vessels in the affected area and in the pia arachnoid. Myelin $\times 1 \cdot 8$. lymphocytic infiltration. In addition focal necrosiô of other areas of the brain, including the brainstemin and inflammatory infiltrates in the pia arachnoid were often present. Typical Cowdry type A intrag nuclear inclusions (Fig. 2) were found in seve cases. Using these criteria in conjunction with the clinical findings, the cases had been diagnosed and

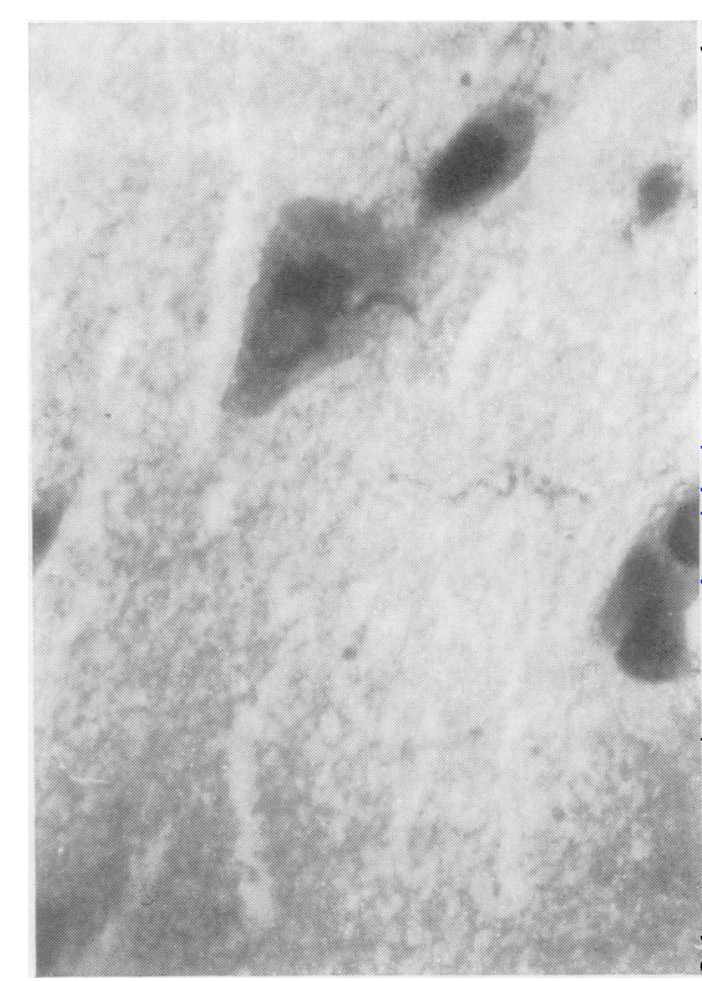

FIG. 2. Intranuclear inclusion body in nerve cell temporal lobe cortex. Haematoxylin and eosin. $\times 118 ?$

filed as herpes virus encephalitis. Viral studies wet? carried out in life or on postmortem material i⿺ four cases with negative results. 


\section{ELECTRON MICROSCOPY}

Cytoplasmic preservation was very poor with marked disintegration of cell organelles, for the material used in this study came from tissues fixed in formalin for long periods or from paraffinembedded blocks. However the nuclei could be clearly seen. As the structure of the nucleus was also altered, partly due to the viral affection and partly due to poor fixation, it was difficult to identify a particular cell type with any degree of certainty. It was, however, our impression that viral particles were present in most instances within the nuclei of nerve cells and only rarely within nuclei of astrocytes or oligodendrocytes. Nuclei containing virus particles usually showed diffuse dispersal of nuclear chromatin and/or areas of clumping. Intranuclear virus particles were found in six out of eight cases.
In all the positive cases virus particles could be seen in one or more blocks from both the temporal lobes and in two also in the frontal lobe. Virus was not found in blocks from other areas in any one of the positive cases. From one of the negative cases a total of 20 blocks, including 10 from the temporal lobes, and in the other three blocks from each of the left temporal and left frontal lobes were examined and virus particles could not be found in any. No virus particles were seen in the numerous sections examined from the control material.

The virus particles (Figs. 3 and 4) were characterized by a central electror-dense core and a surrounding capsid of similar electron density, from which the central core was separated by a less dense halo. The particles were fairly uniform in size, measuring about $90 \mathrm{~m} \mu$ in average diameter. The central core was either spherical or slightly oval

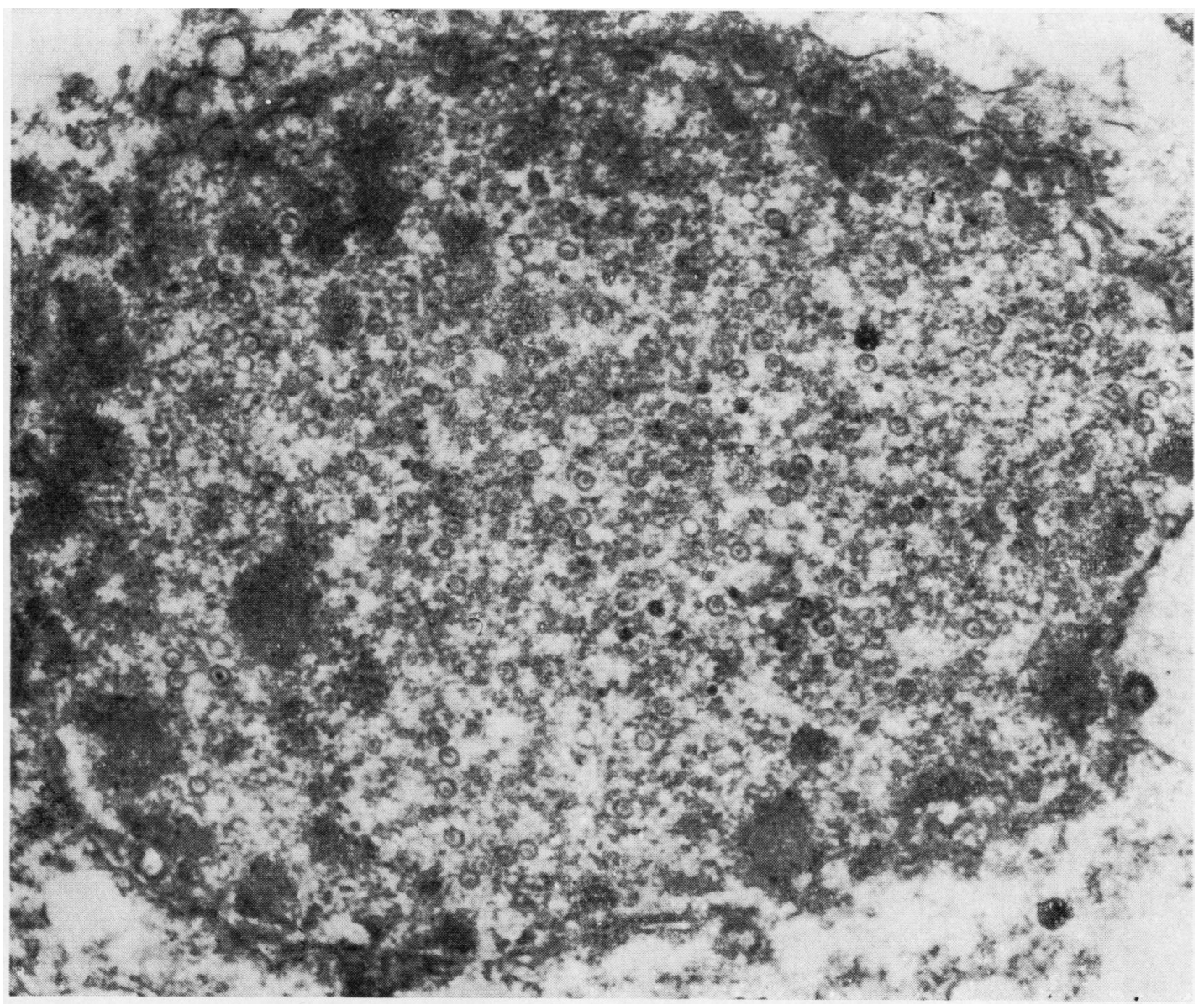

FIG. 3. Electron micrograph showing nucleus with many virus particles scattered throughout the nucleoplasm. Note that the nuclear chromatin is diffusely dispersed with focal areas of clumping. $\times 32,000$. 


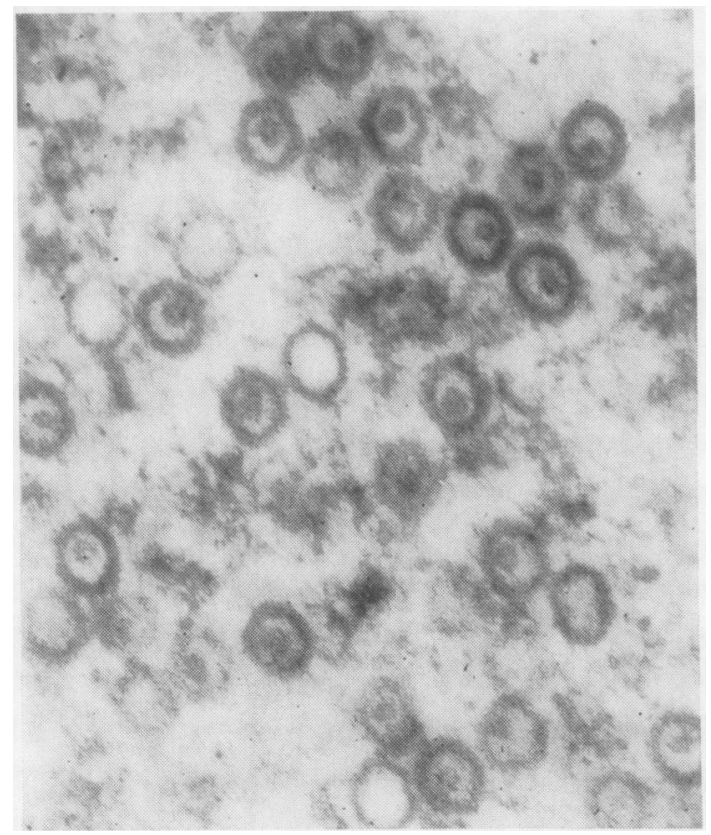

FIG. 4.

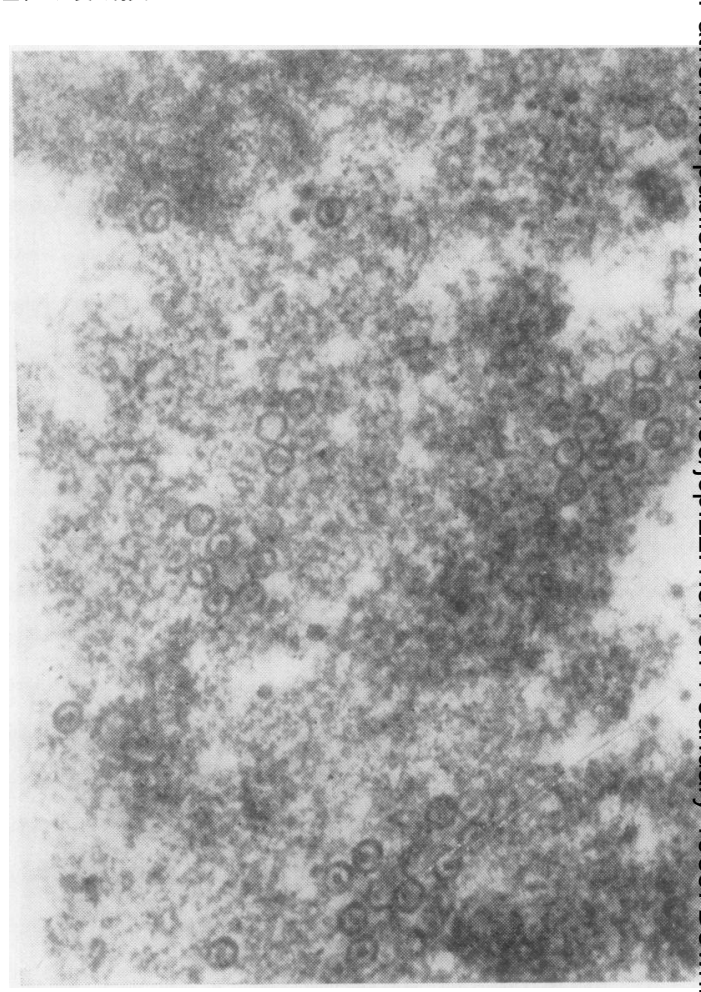

FIG. 5.

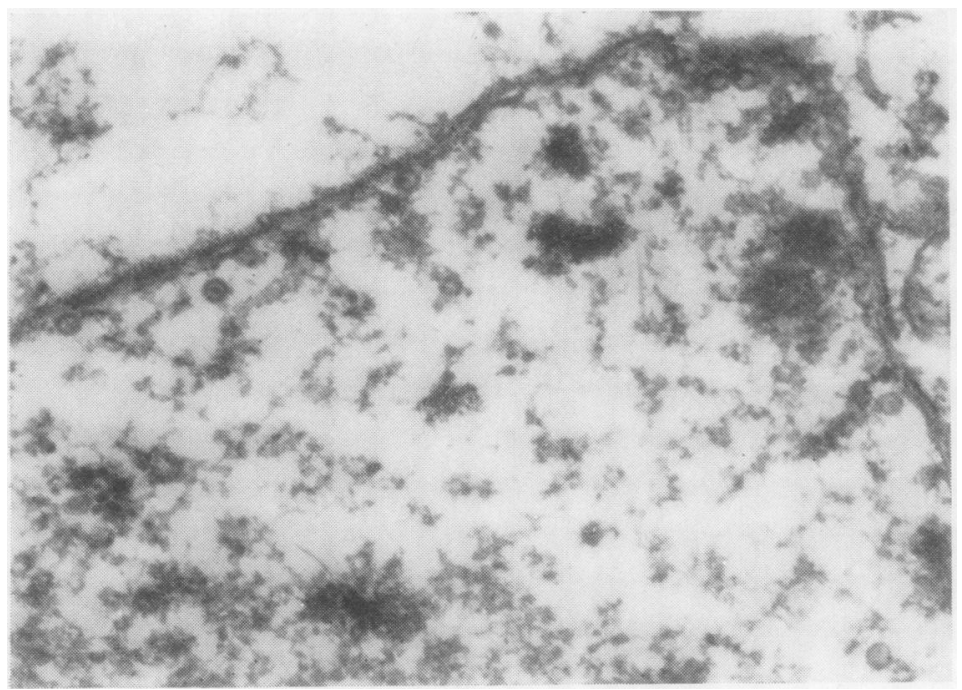

FIG. 4. Intranuclear virus particles at higher magnification. The capsid and nucleoid are clearly visible. $\times 135,000$.

FIG. 5. Part of a nucleus with 으. localized aggregates of virus particla A few particles occurring singly are also seen. Note diffuse dispersalw of the nuclear chromatin. $\times 48,000$ 응

FIG. 6. Part of a nucleus with particles lying close to inner surface of the nuclear membrane. $\times 32,000$.

FIG. 6 . 


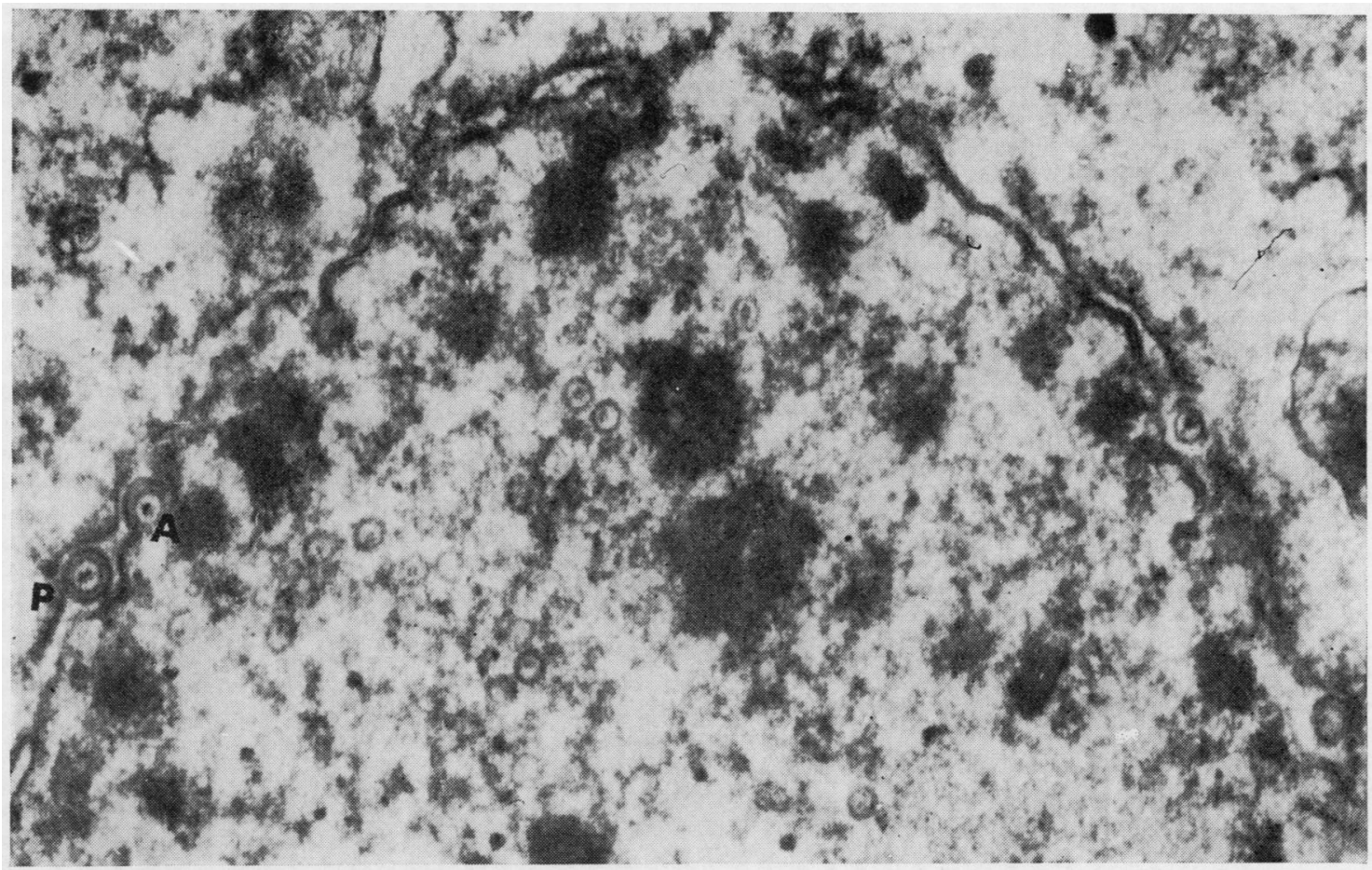

FIG. 7.

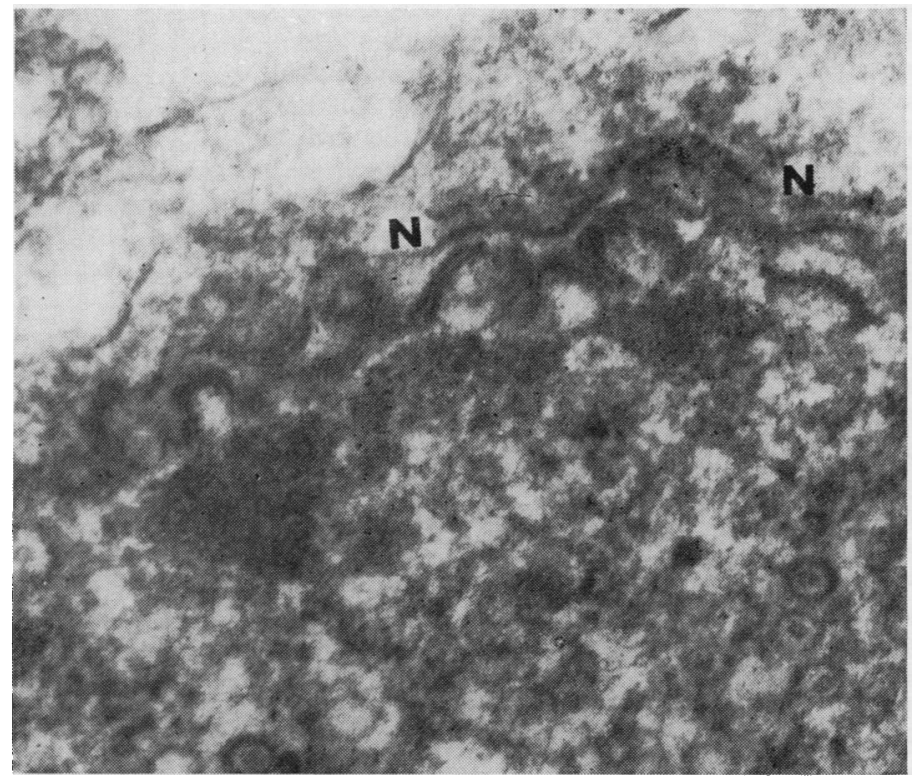

FIG. 7. Part of a nucleus with doublewalled particles $(P)$ within the layers of nuclear membrane. A particle $(A)$ closely applied to the surface of the inner layer of the nuclear membrane is also noted. $\times 48,000$.

FIG. 8. Nucleus containing many virus particles. Note the reduplication of nuclear membrane $(N)$ in some areas. $\times 70,000$.

FIG. 8. 


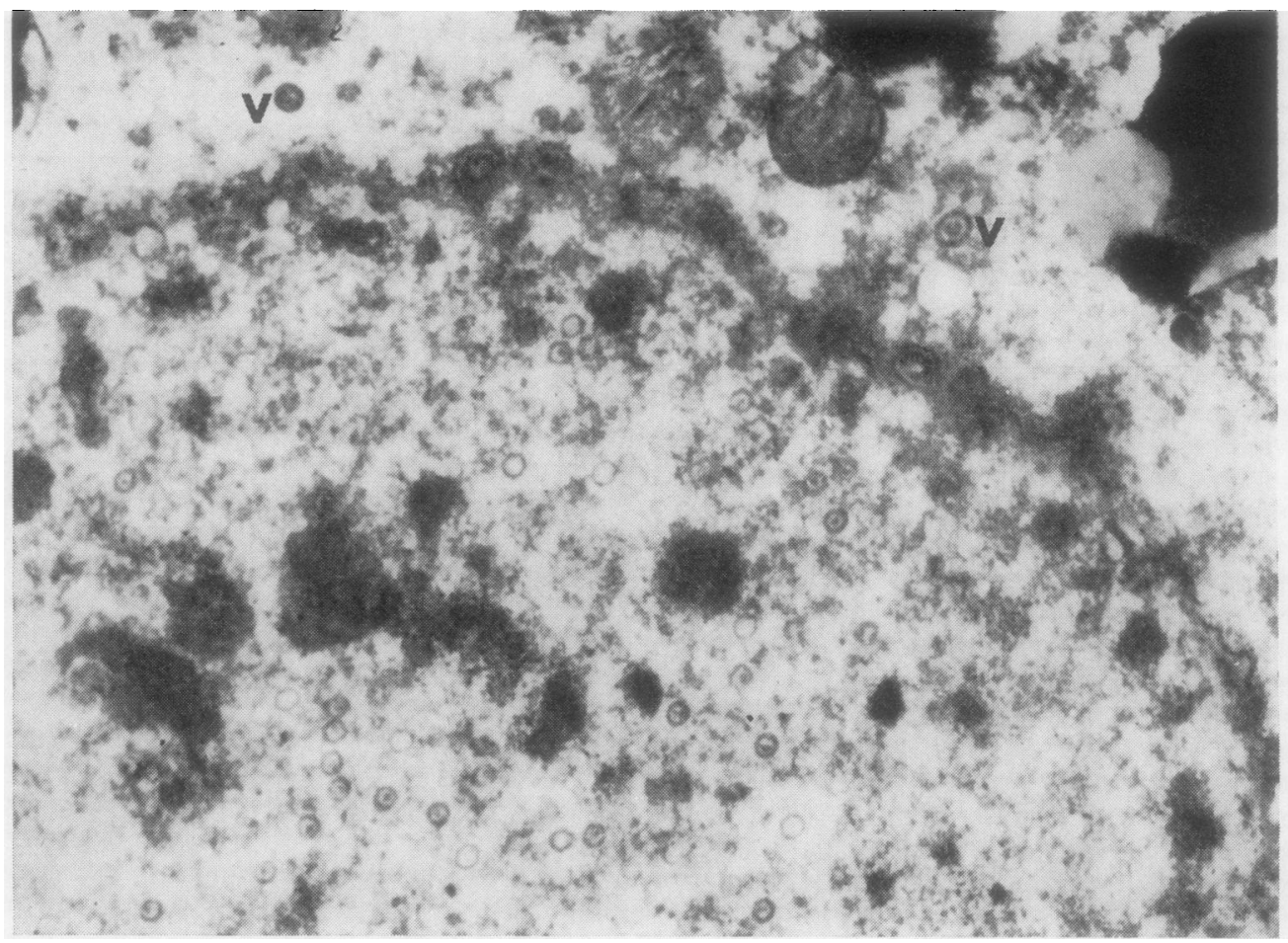

FIG. 9. Scanty virus particles $(V)$ are seen in the cytoplasm with many intranuclear particles and a few on the nuclear membrane. $\times 32,000$.

with a diameter of 30 to $50 \mathrm{~m} \mu$. The capsid consisted of a single membrane which measured approximately $18 \mathrm{~m} \mu$ in thickness. Some of the viral particles did not contain any central core thus giving them an 'empty' look. The particles usually occurred in large numbers in any individual nucleus and were either loosely arranged or more closely packed (Fig. 5). Occasionally only a few particles were present, separated from each other by a wide gap. However, in an individual nucleus more than one particle was always found. In most instances the particles were present well within the nuclei but sometimes they were situated close to the nuclear membrane (Fig. 6) or actually within the layers of the membrane (Fig. 7). Figure 7 also shows a virus particle closely applied to the inner layer of the nuclear membrane. When present in this site the particles were often surrounded by a complete or incomplete second capsule and they were larger, measuring approximately $140 \mathrm{~m} \mu$ in diameter. The nuclear membrane itself often showed reduplication (Fig. 8). Only rarely were they seen in the cytoplasm (Fig. 9).

The particles present on the nuclear membrane should be carefully differentiated from the nuclear pores (Fig. 10) with which these may be confused (Monroe, Schidlovsky, and Chandra, 1967). The nuclear pores in favourable section also showed an outer membrane and a central dot. The overoll measurement of the nuclear pores was slighily smaller than that of whole virus particles and certain other morphological differences distinguished them from the particles of viral origin. Thus the central dot of the nuclear pore was always smaller (12 to $15 \mathrm{r}$ Q $\mu$ diameter) than the central core of viral particles amd the outer membrane of nuclear pores was often indistinct and hazy in contrast to the sharp and distinct outer capsule of the virus particles. Because of tangential section the nuclear membrane vas also indistinct in the region where nuclear potes were seen as round bodies. In an occasional nucleris small, uniformly electron-dense granules were present (Fig. 11).

In this study an attempt was also made to correlate the presence of intranuclear inclusions on ligit microscopy with the finding of virus particles \&y examining respectively serial thick and thin sections from the same araldite-embedded block. In so blocks where numerous intranuclear viral partictes could be seen in the thin section for electron micko- 


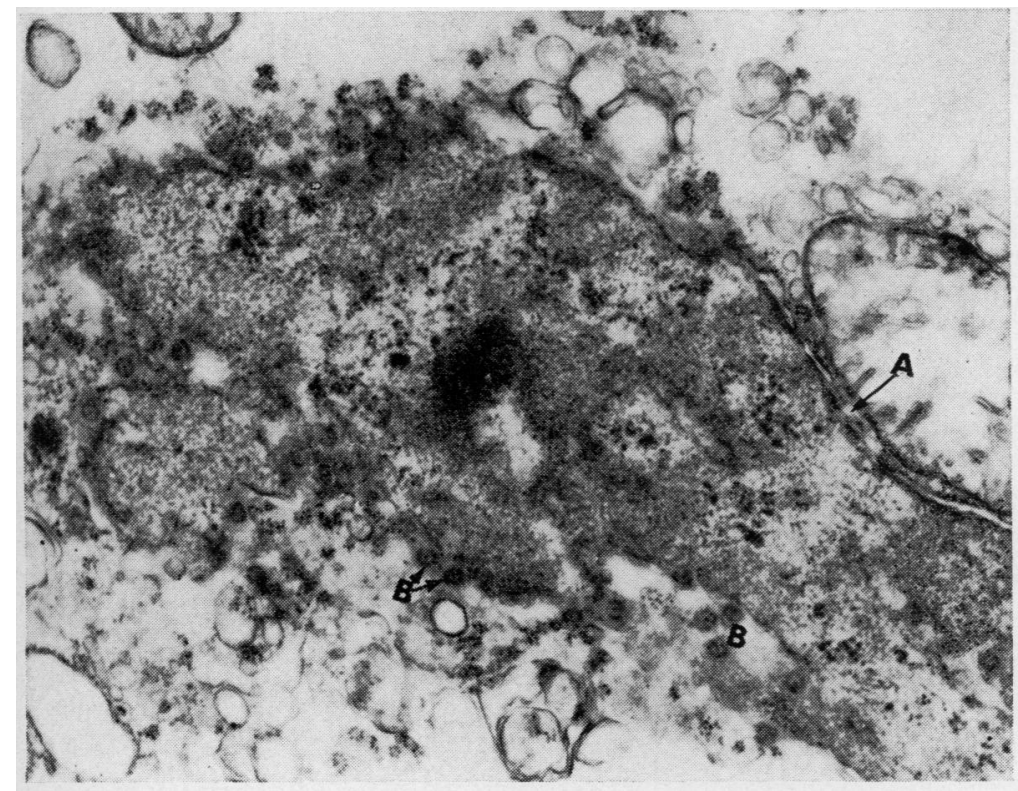

FIG. 10. Nucleus showing nuclear membrane sectioned transversely at $A$ and tangentially at $B$. Nuclear pores appear as pale areas at $A$ and as round bodies with central dot at $B$. $\times 32,000$.

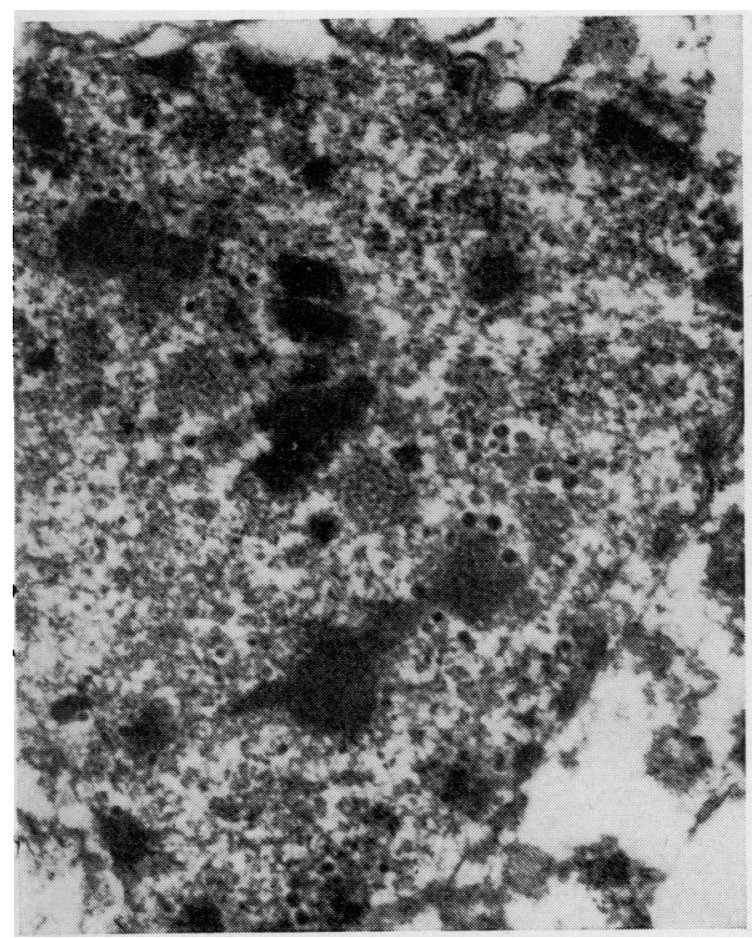

FIG. 11. Many uniformly electron-dense particles without any capsid are seen in this nucleus. Note focal clumping of nuclear chromatin. $\times 32,000$. scopy, a corresponding thick section frequently showed intranuclear inclusions on light microscopy. However, with smaller numbers of particles in thin section, light microscopic examination of thick sections usually did not show any inclusion. This observation seems to support the finding of others that intranuclear Cowdry type $\mathbf{A}$ inclusions are possibly of viral origin (Itabashi, Bass, and McCulloch, 1966; Chou and Cherry, 1967) and not an artifact but all viral aggregates do not present as light microscopic inclusions.

\section{DISCUSSION}

DIAGNOSTIC VALUE OF ELECTRON MICROSCOPY The technique described can be employed to make the diagnosis both in postmortem and in antemortem material, due to the ease with which the relatively large virus particles can be recognized and their stability compared with some of the surrounding cell components.

Herpes simplex virus is now well recognized as a common cause of encephalitis since it was first established as a specific entity by Smith, Lennette, and Reames (1941). In this disease involvement of the temporal lobe is a characteristic feature, first pointed out by Van Bogaert et al (1955) and later confirmed by other workers (Haymaker, Smith, Van Bogaert, and DeChenar, 1958; Bennett, ZuRhein, and Roberts 1962; Pierce, Portnoy, 
Leeds, Morrison, and Wehrle, 1964; Adams and Jennet, 1967). At necropsy, in a typical case showing necrosis of one or both temporal lobes, perivascular lymphocytic infiltrates and Cowdry type A intranuclear inclusions, a diagnosis of Herpes simplex encephalitis can be made with a reasonable degree of certainty. This can be further substantiated by positive virus culture from postmortem material. In some cases, however, a degree of uncertainty remains, especially when no intranuclear inclusions are found and no virus can be grown in culture. Examination with the electron microscope of material from these brains appears to be of great help in establishing the final diagnosis. In this study all eight cases were diagnosed as encephalitis 'possibly due to Herpes simplex virus' on the basis of gross and light microscopic examination of the postmortem material. In four cases, viral study attempted either in life or on postmortem material yielded negative results. However, electron microscopy demonstrated virus particles of Herpes simplex type in six of these, once again confirming the widely held notion that most examples of acute necrotizing encephalitis are caused by Herpes simplex virus. It is not possible to draw any firm conclusion about the cause of encephalitis in the two cases in which no virus particle could be found on electron microscopic examination. In one of these, the patient died $\mathbf{3 0}$ days after the onset of the disease and it is likely that the virus concentration of the brain was minimum or nil at the time of death.

Perhaps the more important use of electron microscopy would be its application in the diagnosis during life of clinically suspected cases. The use of antiviral agent, 5-iodo-2' deoxyuridine (idoxuridine), combined with efficient management to reduce the intracranial tension, has improved the prognosis in these otherwise hopeless cases (Breeden, Hall, and Tyler, 1966; Buckley and MacCallum, 1967; Evans, Gray, Miller, Verrier Jones, Weeks, and Wells, 1967; Bellanti, Guin, Grassi, and Olson, 1968). This antiviral agent has also been effective in treating dermal herpetic disease (MacCallum and Juel-Jensen, 1966). The continuing search for more effective antiviral agents could alter completely the poor prognosis in this disease. To get the maximum benefit from the use of such substances it is essential to institute the therapy at an early stage for which speedy and accurate recognition of the disease is imperative. Of the several diagnostic techniques mentioned earlier, none is very satisfactory for the purpose and some are time consuming. Thus it takes rather a long time (a week or more on an average) to grow the virus on tissue culture in most laboratories and only a proportion of cases yield positive results (Bennett et al, 1962; Drachman and Adams, 1962; Carmon, Behar, and Bellero 1965; Miller, Hesser, and Tompkins, 1966; Itabash et al, 1966). A shorter time to grow the virus has? however, been reported by MacCallum, Potter, an $\Phi$ Edwards (1964) and Herrmann (1967). Measurement. of antibody titre has to be carried out at inters vals for some days to note a substantial in crease before making a diagnosis and it is not very specific (Ross, Sharpe, and Ferry, 1965\% Johnson, Olson, and Buescher, 1968). The fluores:cent antibody technique may be valuable for quickJ recognition of the virus but its usefulness in the diagnosis of herpes encephalitis has not yet bee? established. Light microscopic examination of brain biopsy material may not always help, for it is often not possible to see all the characteristie? histological changes, especially the presence of intrao nuclear inclusions in the small amount of material removed for biopsy examination (Gostling, 1967) although they have been reported in one case by Dodge and Cure (1956). In these circumstances seems that electron microscopy may be a valuable adjunct, and if virus particles are present the diagnoso sis can be made in shorter time (two to three days before virological studies may have been completed MORPHOLOGY AND DISTRIBUTION OF VIRUS PARTICLE The structure of virus particles seen in the present study resembles those of Herpes simplex (Morgan Ellison, Rose, and Moore, 1954; Stoker, Smith, an Ross, 1958; Morgan, Rose, Holden, and Jones 1959; Epstein, 1962; Swanson, Craighead, an Reynolds, 1966; Itabashi et al, 1966; Chou an Cherry, 1967; Harland, Adams, and McSeveney 1967). The fact that they are seen mostly withio the nuclei is also in conformity with the observations of these authors. Particles are sometimes presen within the nuclear membrane and occasionall in the cytoplasm. Morgan et al (1959) and Stoker et al (1958), in their study of cells in tissue culture infected with Herpes simplex virus, also found $D$ similar distribution and postulated that the virus. particles are developed in the nucleus and subro sequently pass through the nuclear membrane into the cytoplasm. These authors also noted that the particles in the nuclear membrane and in the cytoplasm usually have double membranes while those in the nucleus rarely show this phenomenora In the study of Itabashi et al (1966) of human material, double-walled virus particles were only found close to the nuclear membrane. In our studpo we failed to see any double-walled virus particle? within the nucleus or in the cytoplasm but they were frequently observed within the layers of nuclear mem $\mathbb{B}$ brane. In view of the fact that nuclear membrane in infected cells often shows reduplication (Chou and 
Cherry, 1967), it seems likely that the second envelope of the virus particle is usually acquired during its passage through the nuclear membrane into the cytoplasm. Occasionally the second envelope may also develop within the nucleus (Morgan et al, 1959). However, the absence of a double membrane in cytoplasmic virus particles in our material cannot be easily explained. The possibility is that the outer envelope is less stable and is destroyed with other cell organelles in poorly preserved material as used in our study of old formalin-fixed tissues.

The electron-dense intranuclear granules, occasionally seen in our sections (Fig. 11), are similar to those observed by Morgan et al (1959) in infected cells in tissue culture. Such granules were seen in cases 2 and 4 but were not found in control specimens and it seems likely that they represent either a phase in the development of virus or a change in the nucleus due to virus infection. The recent demonstration of the rapid penetration of the nucleus by viral DNA after uncoating within the cytoplasm of cells infected by Herpes simplex in tissue culture before replication commences (Hochberg and Becker, 1968) offers some support for the former possibility.

It is a pleasure to acknowledge the kindness of Professor W. A. J. Crane, of the Pathology Department, University of Sheffield, in allowing us facilities in his department and for the help of his technical staff.

This work was supported by a grant from the National Fund for Research into Crippling Diseases.

\section{REFERENCES}

Adams, J. H., and Jennett, W. B. (1967). J. Neurol. Neurosurg. Psychiat., 30, 248.

Balfour, H. H., Jr, Loken, M. K., and Blaw, M. E. (1967). J. Pediat., 71, 404.

Bellanti, J. A., Guin, G. H., Grassi, R. M., and Olson, L. C. (1968). Ibid., 72, 266 .

Bennett, D. R., ZuRhein, G. M., and Roberts, T. S. (1962). Arch. Neurol. (Chic.), 6, 96.
Biegeleisen, J. Z., Jr, Scott, L. V., and Lewis, V. Jr, (1959). Science, 129' 640.

Breeden, C. J., Hall, T. C., and Tyler, H. R. (1966). Ann. intern. Med., $65,1050$.

Buckley, T. F., and MacCallum, F. O. (1967). Brit. med. J., 2, 419. Carmon, A., Behar, A., and Beller, A. J. (1965). J. neurol. Sci., 2, 328. Chou, S. M., and Cherry, J. D. (1967). Neurology (Minneap.), 17, 575.

Dodge, P. R., and Cure, C. W. (1956). New Engl. J. Med., 255, 849.

Drachman, D. A., and Adams, R. D. (1962). Arch. Neurol. (Chic.), 7,45 .

Epstein, M. A. (1962). J. exp. Med., 115, 1.

Evans, A. D., Gray, O. P., Miller, M. H., Verrier Jones, E. R., Weeks, R. D., and Wells, C. E. C. (1967). Brit. med. J., 2, 407.

Glauert, A. M. (1961). In Techniques for Electron Microscopy, edited by D. Kay, p. 179. Blackwell, Oxford.

Gostling, J. V. T. (1967). Proc. roy. Soc. Med., 60, 693.

Grist, N. R. (1967). Ibid., 60, 696.

Harland, W. A., Adams, J. H., and McSeveney, D. (1967). Lancet, 2, 581.

Haymaker, W., Smith, M. G., Van Bogaert, L., and De Chenar, C. (1958). In Viral Encephalitis, edited by W. S. Fields and R. J. Blattner, p. 95. Thomas, Springfield, Ill.

Herrmann, E. C., Jr (1967). Mayo Clin. Proc., 42, 744.

Hochberg, E., and Becker, Y. (1968). J. gen. Virol., 2, 231.

Itabashi, H. H., Bass, D. M., and McCulloch, J. R. (1966). Arch. Neurol. (Chic.), 14, 493.

Johnson, R. T., Olson, L. C., and Buescher, E. L. (1968). Ibid., 18, 260.

Lynn, J. A., Martin, J. H., and Race, G. J. (1966). Amer. J. clin. Path., $45,704$.

MacCallum, F. O., and Juel-Jensen, B. E. (1966). Brit. med. J., 2, 805.

- , Potter, J. M., and Edwards, D. H. (1964). Lancet, 2, 332.

May, G., Dahn, R., and Reuss, K. (1967). Germ. med. Mth., 12, 377.

Miller, J. K., Hesser, F., and Tompkins, V. N. (1966). Ann. intern. Med., 64, 92.

Monroe, J. H., Schidlovsky, G., and Chandra, S. (1967). J. ultrastruct. Res., 21, 134.

Morgan, C., Ellison, S. A., Rose, H. M., and Moore, D. H. (1954). J. exp. Med., 100, 195

- Rose, H. M., Holden, M., and Jones, E. P. (1959). Ibid., 110, 643. Palade, G. E. (1952). Ibid., 95, 285.

Pierce, N. F., Portnoy, B., Leeds, N. E., Morrison, R. L., and Wehrle, P. F. (1964). Neurology (Minneap.), 14, 708.

Rawls, W. E., Dyck, P. J., Klass, D. W., Greer, H. D. III, and Herrmann, E. C., Jr (1966). Ann. intern. Med., 64, 104.

Reynolds, E. S. (1963). J. Cell Biol., 17, 208.

Ross, C. A. C., Sharpe, J. H. S., and Ferry, P. (1965). Lancet, 2, 708.

Smith, M. G., Lennette, E. H., and Reames, H. R. (1941). Amer. J. Path., 17, 55.

Stoker, M. G. P., Smith, K. M., and Ross, R. W. (1958). J. gen. Microbiol., 19, 244.

Swanson, J. L., Craighead, J. E., and Reynolds, E. S. (1966). Lab. Invest., 15, 1966.

Van Bogaert, L., Radermecker, J., and Devos, J. (1955). Rev. neurol., 92, 329.

Wolman, L. (1967). Publ. Hlth. 81, 58. 